\title{
Justice and Its Relevance in Curtailing Security Challenge in Nigeria
}

\author{
Muhammad Dahiru Shuni, Attahir Shehu Mainiyo \\ Department of Islamic Studies, Usmanu Danfodiyo University, Sokoto
}

\begin{abstract}
Justice is nothing but rather putting things on their proper positions, this, if done will no doubt brings about peace and stability in any society and failure to this will bring about instability, acrimony and friction. It is the instrumental to the endurance of the state, security and well being of mankind, all those involved in learning and earning cannot do without security from good governance founded on justice, for instance professionals like doctors, administrators and craftsmen cannot carry out their occupations effectively without security and prosperity that result from the actions of a just government. It can therefore be said that, the current crisis and instability in the country -Nigeria can be attributed to the absence of justice particularly from the leadership circle. This is because it is the bedrock of any meaningful development in the society and when lacked, the door for every calamity is opened and this includes oppression and insecurity. In fact, the success of any leadership defends solely on its dispensation of justice. Sultan Muhammad Bello has said in one of his writings that there would be no development in any government without observance of justice. He observed that:

There is no government except with soldiers and there are no soldiers without money and there is no money without Kharaj (Tax) and there is no tax without economic development and there will be no development without justice. ${ }^{l}$

Moreover, for peace and the security to prevail in our dear country the cardinal principle of justice must be adhered to. Following this background, this paper intends to look at this principle of justice in Islam and show its relevance in curving the current security challenges in Nigeria.
\end{abstract}

\section{Introduction:}

Islam is a religion of justice; its sole purpose is to ensure justice in every sphere of life. Its political and legal systems aim at providing universal justice to all and sundry. In addition to this, all the institutions established by Islamic political and legal system are basically structured in a way that they ensure the delivery of justice. It is perhaps the most important of all the supreme values of Islam. In fact, it can be said that the main purpose of revelation and the tasks of all the Messengers of Allah (A.S) had been to establish a just order in the world. Justice is the first principle of social life. It is to govern all relations in life: between ruler and ruled, rich and poor, husband and wife, parents and children. Even in the ordering of an individual's personal habits, justice must be done to the respective requirements of body, mind and spirit. It is unjust, for example, to neglect your body and its needs in search of spiritual development. It was in line with what the Prophet (SAW) has clearly enunciated in one of his tradition that one should give the right to everyone to who it is due.

In all our dealing, we are required to stand firmly for justice even if it be against ourselves and our kith and kin, for love too can lead to injustice.

Allah says:

And if you give your word you must be just, even though it be against your kin, and fulfill the covenant of God. For that is what He has commanded you that you may remember. ${ }^{2}$

All the Prophets and messengers of Allah strived for the establishment of justice in all aspects of human life. It is the only system which has been implemented in letter and spirit for centuries in many different cultural environments and societies. This is a unique feature in Islam.

\section{Meaning Of Justice:}

Justice means fairness, impartiality, equitableness, objectivity, neutrality, just conduct or the exercise of authority in the maintenance of right. ${ }^{3}$ In Arabic its equal is ' $A d l$ which means to place things in their rightful position.

The term is found both as substantive and as an adjective. It means rectilinear, just and well balanced. It thus applies to both beings and things. ${ }^{4}$

Plato observes that, "what is due to every man is that he should be treated as what he is, in the light of his capacity and his training, while what is due from him is the honest performance of the work which the position assigned to him requires.", 
He speaks of justice in terms of services and functions which the individuals perform with regard to state. State according to him is created by mutual needs and hence services are to be reckoned with in describing justice. The individual has no intrinsic value except that his value lies in the performance of work for the state. From Islamic point of view, social justice may be defined as the principle of Divine law. The following are some of the components of social justice:

1. To treat man as individual with liberty and equality as his birth right

2. To provide him with equal opportunities of developing his personality so that he is better fitted to the situation to which he is entitled,

3. To give such individual his due wherever his/her course of life may lie and

4. To regulate his/her relation with society in such a manner that, far from being harmful, he/she contributes his /her own to its moral value and welfare. ${ }^{6}$

\section{QUR'AN AND SUNNAH ON JUSTICE:}

The following texts of Qur'an are worth mentioning when talking about justice in Islam.

Allah declares that:

O you believers, Stand out firmly for Allah, and be just witnesses and let not the enmity of people make you avoid justice...?

And in another place He states:

He also mentions that:

$$
\text { Verily Allah enjoins justice... }{ }^{8}
$$

...say I believe in whatsoever Allah has sent down of the Book and I am commanded to do justice among you...'

In yet another place He explains that:

Be just that is nearer to piety. ${ }^{10}$

He then said that:

There is no God but He: that is the witness of Allah, His angels and those endowed with knowledge standing firm on justice. ${ }^{11}$

He further expounds that:

We sent aforetime our messengers with clear signs and sent down with them the book and the balance of right and wrong that men may stand forth in justice. ${ }^{12}$

It is worth mentioning that Allah has created the whole universe with a particular measure or balance and man has been asked to observe it strictly. It was in the same line that Almighty Allah reveals that:

And the sky He has uplifted; and He has set the measure, that you may exceed not the measure, but observe the measure strictly, nor fall short thereof. ${ }^{13}$

The measure and balance refer to justice, the heavenly virtue which should be established among all types of men who constitute a society. Man has to act justly with him and the world around him.

In another place He mentions:

Allah commands you to render back trusts to those to whom they are due and that when you judge between people, judge with justice, surely Allah admonishes you with what is excellent. ${ }^{14}$

There are many traditions of the Prophet Muhammad (S.A.W) which emphasize on the principle of justice as did by the Qur'an. The Prophet (S.A.W) remarked:

Whoever is entrusted with the affairs of the Muslims and he delegates part of it to a man while he knows a better one for it, he is a traitor in the eyes of Allah and His Messenger. ${ }^{15}$

A group of men visited the Prophet (peace be upon him) and asked him a governmental post. He replied,

We do not install in our offices those who ask for it. ${ }^{16}$ 
Once the Prophet (peace be upon him) said to 'Abdurrahman bin Samrah:

O Abdurrahman, never ask for a post, if it is given to you without your demand, you left to it on your own. ${ }^{17}$

The Prophet (S.A.W) further emphasized that:

Whoever asks for the position of judge and makes others intercede in his favour will be left in it to his fate and whoever is entrusted with it without his demand and without asking others to intercede in his favour, Allah will send down an angel to direct him in it aright. ${ }^{18}$

The Prophet (SAW) was also reported to have said:

When the trust is lost, then the Last Day is at hand," the Companions asked, "how can it be lost?" He replied, when the offices are assigned the people not worthy of these offices, it means that the Last day is at hand.

Muslims are unanimous about the fact that the guardian of a minor, the custodian of a endowment and a legal representative should administer the affairs entrusted to them in the best of their knowledge and effort. ${ }^{19}$

Allah, the Exalted enunciates:

...and don't approach the property of orphan except in the best possible manner... ${ }^{20}$

The Prophet (S.A.W) also gave further explanations:

Everyone of you is a shepherd and everyone of you is responsible for his flock, the caliph who rules the people is shepherd and is responsible for those whom he governs, the woman is a shepherd in her husband's household and is responsible for what is under her supervision, the servant is a shepherd as regards his master's wealth and is responsible for it and a man is shepherd with respect to the wealth of his father and is responsible for what is under his supervision, Lo! Every one of you is a shepherd and is responsible for his flock. ${ }^{21}$

He further cautions that:

Any ruler to whom Allah has entrusted His flock and who dies one day after having cheated his subjects; Allah will not allow him to smell the fragrance of paradise. ${ }^{22}$

The Prophet (S.A.W) made mentioned that seven categories of believers will be given place under Allah's shade on the Day while no other shade will be available except His. The first among those mentioned is a just ruler. ${ }^{23}$

A companion entered the court of Muawiyah (R.A) and greeted him by calling him as hireling ( ajir). The people there told him to call him as Commander of the Faithful but he insisted to call him 'hireling' and Muawiyah allowed him to do that. Then he explained, "You are a hireling whom the Lord of these sheep has hired to take care of them. If you tar the itchy among them and cure the sick and put the surplus of the more advanced at the service of the poor, their Lord will reward you in full. If you, on the contrary, do not tar the itchy nor cure the sick nor put the richer at the service of the poorer, their Lord will punish you." ${ }^{4}$

Islamic history is a witness to the fact that Muslim rulers understood the significance of administration of justice. The ideal period in this respect was, no doubt, the earliest era of the Prophet (S.A.W) and his Companions particularly the rightly guided caliphs.

In a letter sent by Umar (R.A) to Abu Musa al- Ash'ari the functions of judiciary were laid down, the letter harped on the administration of justice. He said that, court must ensure equality between the parties so that the weaker party may expect justice and the stronger may not expect concession. The burden of proof is on the plaintiff and the defendant may be put on oath but let this not defeat the ends of justice and law. ${ }^{25}$

In this letter, Umar (R.A) has explained the basic principles of administration of justice through courts. But Islam does not only inspires its followers to adhere to the rules of formal justice, rather it creates a characteristics of watchfulness in its followers which, at times, persuades them to bring themselves to justice without any external force making them to do that. Relatively, "Umar (R.A) once went out carrying a skin for fetching water, his son shown his dismay on what he did, he said him "why are you doing this?" Umar replied," I am contented and I must humble myself." Here is a man who can recognize in the depths of his soul a pride in his office as Caliph, in his conquests and greatness which he has attained and unwilling that such pride should continue. So he determines to humble himself in the right of all his subjects. ${ }^{26}$ 
The theory behind the administration of justice in Islam is based on unique principles and the fountain head of same is Quran as the legislative sovereignty of the Muslim community.. ${ }^{27}$

As Qur'an, Sunnah and practice of Ummah throughout the history is a witness to the fact that the administration of justice is the primary purpose of Islamic legal and political systems, it is therefore imperative upon the Muslim Ummah that this important mission should be strived for by its representative rulers and it should be carried out completely i.e. all the basic departments of the administration of justice should be brought into action.

\section{RELEVANCE OF JUSTICE IN CURTAILING SECURITY CHALLENGE IN NIGERIA}

As this article highlighted, the bedrock of any leadership is its justice system. This concept is meant to give everyone his due right. A leader, therefore, should be impartial in dealing with his subjects for the sake of public interest. Whenever the leadership circle became partial in dealing with their subjects this may cause the wrath of Allah and it can lead to any level of instability, for the rights of certain class of people were denied. However, Leadership is a great quality and every great organizational success, besides other factors, owes its credit to the leader who led it to glory. Small groups; families, organizations, states, empires and even the world at large need good leaders who can lead their respective followers and organizations to success.

Every human endeavor needs a unifying and driving force for success and that driving force is ultimately traced to good leadership. We are therefore much convinced that the Islamic Leadership principles practiced by the Prophet Muhammad (SAW) and subsequently by his Caliphs and pious followers which if practiced today will provide successful administration and implementable principles and will equally be useful for both Muslims and non Muslims as well.

More so, the injustice been mated on the masses in the contemporary Nigeria has helped greatly in bringing insecurity in the country. Whenever the right of people is denied they are provoked and whenever people are provoked then anything can happen as is the case now. Many (if not all) of those in leadership do favour their relatives, friends, and members of their political parties when it comes to certain matters, be it awarding contracts, provision of social amenities and even rendering some sort of assistance he or she deserved so long as he/she did not belong to any of the classes mentioned above he/she will not be considered and this is out rightly injustice. Concerning the use of public funds, a leader should not misuse the funds even his salary should not be higher than other employees, who have many dependants under them. It is in line with this that the leadership in Islam is considered as an amanah (a trust) and a responsibility. A leader is therefore required to meet his obligations to Allah, the Supreme Power as well as to discharge his duties towards the people (Makhluq) or his followers to the best of his abilities. Adalat Khan is of the view that the authority vested in them (rulers) is not their private property but is a trust and that they should discharge the obligations of that trust to the utmost, like upright and honest people, and should carry on government in consultation with the people. It says to the ruled, the power to choose your rulers has been bestowed upon you as a gift from God and you should, therefore, be careful to invest only such persons with governing authority as fully deserve it, and after vesting this authority in them, you should give them your fullest cooperation and should not rebel against them, for if you do so, you are merely seeking to demolish that which your own hands have built.

But in the contemporary Nigeria, public funds are being looted by those occupying high positions thereby spending the money stolen in purchasing luxurious cars, building monsoon houses and wearing expensive clothes etc. During the Caliphate of Umar (RA) whenever an official is appointed he will be warned to shun luxury and ostentations or be dismissed. This attitude which became prevalent among some class of leaders in the country is share injustice as the money is meant for services to be rendered to people but channeled to other means for a reason best known to them. It should be of great importance that a leader must ensure that Justice and Compassion are exhibited in all his dealings which form the core of Islamic Leadership. That is why Justice without compassion leads to tyranny, while compassion without justice creates anarchy. A leader needs to maintain a careful balance keeping the overall good of society in mind.

Another form of injustice is having favorites among the subjects, doing so causes him to lose respect, and the people he favours would be hated by others, in as much as the leader loses respect from his subjects they will not listen and regard whatever he says. Similarly, he should try his best not to fall into the trap of partiality, hence creating enmity among different groups of people. Partiality here could be in many ways, for instance, if a leader wants to appoint some officers, he should not be partial, probably by appointing those he likes and neglecting those he hates, even if they are more competent than those who are his favorites. Justice must be done to every citizen irrespective of his political, ethical, or religious belief and, unless this is done by Nigerian leaders the aim of leadership would not be achieved.

The most security challenges in the contemporary Nigeria are the issues of corruption, Boko haram and Niger Delta militants. If one analyzes these challenges, one will find out that they are as a result of injustice 
particularly from the leadership. Let us look at the issue of corruption as an instance many are of the belief that if the leadership is not corrupt the country has enough resources to cater for the need of the majority of the populace but it happens that only few out of the millions will loot all that is generated from nation's resources, the common man is left in hunger, illness, poor education, in addition he has no access to good roads, no electricity and many other basic amenities he may requires. A person in this condition can easily join any gang of evil people who will start from robbery to terrorism, and the root of all these is injustice from the leadership circle.

Similarly, when people talk about security nowadays the issue of Boko haram will dominate the whole discussion, we need to look at how the crisis started, suppose that the justice is done to the followers of the organization at the beginning the country would have not experienced this alarming condition of insecurity from the sect. The members of the group were arrested and killed without trial and their leader was also killed without any judicial hearing then how one would expect other members of the group to react? What government should have done, in the view of some Nigerians, is to take their case to court and file a case against them for the next line of action to be taken and not to take the law in to their hands.

The activities of Boko- haram, particularly in the northern part of the country, have actually taken a new dimension. Even Niger Delta militants, going by what it claims, one realizes that it is as a result of injustice from their leaders. The group is of the view that the region finances the country from oil production from the area but no meaningful projects were executed in their areas despite huge amount of money been allocated to their respective states monthly.

It can therefore be said that the group came about as a result of the injustice from their leaders, for if they are provided with all they needed probably the name MEND wouldn't have came into existence.

A leader is expected to organize a forum whereby members of the lower class of the society could have an opportunity to lodge their complaints. This is important because the complaints might be against their leaders. In a situation where this immunity exists, there must be instability and injustice and this would lead to the termination of that leadership, for no leadership survives without justice. It is also part of justice of leadership that a leader makes himself available at all times in a public place. This would enable his subjects channel their grievances.

Furthermore, even if the ruler appointed some deputies still he should made himself available. This is because complaint might be channeled on the assigned deputies. The four rightly guided caliphs had removed some righteous people from offices due to the complaints made against them. Not only leaders, the officials of the state are also encouraged in the dispensation of justice and to start with themselves by allowing their religion and sound reason to control their emotion and desire. Sultan Muhammad Bello stressed this idea in Usul al-Siyasah where he commanded the rulers to instruct their subjects to do justice and to avoid injustice. Shaykh Uthman Bn Foduye had also mentioned justice as one of the foundation of government and where it is lacking the building will automatically collapse. Justice is therefore expected from every angle.

\section{References:}

[1]. O.Bello (Ed and trans) M.Bello Al-Ghaith Wabil fi Sirat Imam Adil, School for oriental and African Studies London 1983 p.340

[2]. Surah 6 Verse 152

[3]. U. Laurence, The Oxford Thesaurus,(Oxford: Clarendon Press, (1992) p. 234. See also The Concise Oxford Dictionary :Oxford: Clarendon Press, 1990 p. 642,

[4]. H.A.R.Gibb et.al. The Encyclopaedia of Islam (Leiden, E.J. Brill, , 1991), 1/141

[5]. For more details see:The Columbia Encyclopedia, Sixth Edition 2008, available at: http://www.encyclopedia.com/topic/Plato.aspx, accessed 4-3-2010

[6]. Ibid. p. 129

[7]. Al Qur'an 5: 8

[8]. Al Qur'an 16:90

[9]. Al Qur'an 42:15

[10]. Al Qur'an 5:8

[11]. Al Qur'an 3:18

[12]. Al Qur'an 57:25

[13]. Al Qur'an 55:7,9

[14]. Al Qur'an 4:58

[15]. Muslim

[16]. Sahih Bukahri, Hadith NO. 6730

[17]. Sahih Muslim, Kitab al Imarah, Bab: Annahy 'an talab al marah wa al hirs alayha, Hadith No 3401

[18]. Abu Dawud, Kitab al udhiyyah bab: fi talab al Qada wa al tassaru c ilayhi, Hadith No 3107,

[19]. Dr. Omar A. Farrukh, Ibn-i-Tamiyyah on Publilc and Private law in Islam or Public Policy in Islamic Jurisprudence (Beirut: Khayat Book and Publishing Co. 1966) p. 19

[20]. Al Qur'an6: 152

[21]. Sahih Bukahri, Kitab al Istiqrad wa ada' adduyun wa al hajr wa al taflis, Bab; al 'abdu ra'in fimal-i-sayyidihi wa la y'amalu illa bi idhnihi, Hadith No 2232

[22]. Sahih Muslim, Kitab al 'iman, Bab: Istihqaq al wali al ghash li r' 'iyyatihi annar, Hadith No 203

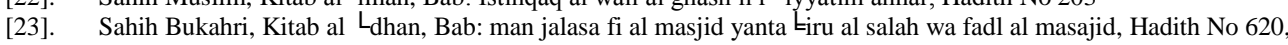

[24]. Dr. Omar A. Farrukh, in Ibn-Tamiyyah on Public and Private law of Islam, op.cit. p.20

[25]. Al Haj Muhammad Ullah, The Administration of Justice in Islam (New Delhi, Kiab Bahavan, ,1990), p.6

[26]. Syed Qutub, Social Justice in Islam, (trans.) John B. Hardie(New York, Islamic Publications International, 2000), p. 183

[27]. Anwar Ahmad Qadri, Justice in Historical Islam (Lahore: Shaikh M. Ashraf, 1974), P.2. 